\title{
COUNTERSTORIES, STOCK CHARACTERS, AND VARIETIES OF NARRATIVE RESISTANCE
}

\author{
RESPONSE TO LINDEMANN
}

Mark Lance

$\rrbracket$

HAVE BEEN THINKING quite a bit over the last two years about Hilde Lindemann's work on our narratively structured holding of one another in personhood. I am broadly sympathetic to her approach: to the idea that a necessary dimension of personhood is being given communicative uptake, to the implication that this both allows us to constitute dimensions of positive freedom and at times constrains us in ways that can constitute oppression, and finally to the suggestion that the available patterns of uptake and understanding are themselves constituted, partly, by socially available narratives.

We are initiated into personhood through interactions with other persons, and we simultaneously develop and maintain personal identities through interactions with others who hold us in our identities. This holding can be done well or badly. Done well, it supports an individual in the creation and maintenance of a personal identity that allows her to flourish personally and in her interactions with others. Done badly, we hold people in invidious, destructive narratives. ${ }^{1}$

In "Counter the Counterstory," Lindemann engages directly with the cases in which the narrative constitution of lives is directly oppressive, where the kind of character we are socialized as, on the basis of widely available narratives involving instances of our many identities, cuts off possibilities, damages our potential for flourishing, or leaves people in a socially dominated position. Her goal is to begin articulating ways that "counter-narratives" can challenge oppressive narrative formations, and the reactionary tactics they mobilize to defend against such challenges. I find myself in broad agreement with the claims and, maybe more important, welcome reflection on this social dynamic of narrative and counter-narrative. Indeed, I find this all to be one important vector in the philosoph-

1 Lindemann, Holding and Letting Go, $\mathrm{x}$. 
ical study of activism - a dimension of human experience that was largely ignored in twentieth-century Anglo-American philosophy, and which is only just becoming an explicit topic. For this reason, especially, I welcome the current contribution.

In section 1 of this paper, I discuss one mechanism by which widely available narratives provide models for social lives via the institution of "stock characters" that function as themes upon which living improvises. My aim is not to offer anything like a theory of the constitution of the self here, nor even at the level of metaphor to suggest that this is the only mechanism by which narrative influences the selves we hold one another to. Rather, my goal is to highlight some vulnerable joints and pressure points at which social pushback against oppressive narratives can gain purchase. In section 2, I emphasize some additional ways that these narratives can be oppressive. Finally, in section 3, I extend Lindemann's discussion by illustrating some of those forms of pushback.

\section{WHAT'S NARRATIVE GOT TO DO WITH US?}

For convenience, let us call the socially shared stories that everybody knows the master narratives of that society. Many fairy tales qualify as master narratives - think of "Snow White" or "Goldilocks and the Three Bears"- and so do nursery rhymes such as "Humpty Dumpty." Children's books such as the Harry Potter series and the Shakespearean plays Hamlet and Macbeth count too. So do the biblical tales of Adam and Eve, Samson and Delilah, and the Prodigal Son.

Master narratives are crucial for any social interaction, because they depict how we are supposed to behave in specific settings. ${ }^{2}$

On an overly literal reading of such passages, one could think that the story goes like this: certain stories have near-universal uptake. People in various groups are supposed to identify with particular characters in the story and society demands that they live out their lives as the character does. But the obvious objection here is that none of us live with talking bears or Shakespearean witches. Society does not demand that women cut the hair of superhero lovers. So we certainly do not literally follow the story.

Of course one can view the stories more abstractly, as a story about being a submissive or vengeful woman. But the worry is that if we understand narratives such as these at a level of abstraction sufficient to allow them to apply to actual life, then the narrative features are not doing much work. Why not simply say

2 Lindemann, "Counter the Counterstory," 287-88. 
that society has rules —-women should be submissive-rather than that stories define us?

Lindemann, in fact, makes it clear that this is not the right way to think about narrative constitution when she emphasizes that it is "the tissue of stories that constitute the group's identity." ${ }^{3}$ It is not that we are taught by society to read our behavior off of a single story, but that we have a cluster of stories for each dimension of identity, clusters that determine both how we are meant to understand ourselves and how society gives us uptake. Many stories have a character of a mother, for example. While these mothers do very different things in very different situations, commonalities of behavior, character, and motivation emerge from our exposure to them. The idea, I suggest, is not that we memorize a list of imperatives - if in this situation a person of type $t$ must do $x$ - but that we come to grasp a "stock character."

While offering nothing close to a theory, I think this literary trope is helpful in understanding the way that social narratives shape self- and other-understanding. A stock character, recall, is a stereotypical or archetypal character that can be seen as re-appearing in multiple stories. From the ancient Greek characters of Theophrastus and the epic heroes of national founding myths, to the hardboiled detectives and femme fatales of film noir, literature is replete with stock characters. However, exactly, it is that we come to such a conceptualization-my goal is political strategy not cognitive science-we do recognize, say, the cynical hard-boiled detective when we see him. And when we do recognize him as such, we extrapolate typical behavior from past literary appearances of that character, even across wildly different contexts. (Rick Deckard in Blade Runner is immediately familiar to us, as an instance of a type that includes Philip Marlowe.)

Of course stock characters do things that surprise us. (Literature would be really boring otherwise.) So what exactly is it for something to function as a stock character? I suggest first that for there to be a stock character in a society just is for that society to recognize instances as of that stock character. So what is it to recognize someone (real or fictional) as of a stock type? Without offering anything like a complete analysis or theory, I suggest that such an understanding involves the following elements.

First, the recognition of Philip Marlowe as of the type [noir detective] provides us a sort of explanatory template. To understand him as of this type means that certain actions will appear "in character"-a cynical sneer, an unhealthy whisky and cigarette habit, a certain cavalier relationship to legal niceties and sexual consent. Someone understanding Marlowe as of the type will automatically see all this as natural. He is that character; that is what such characters do.

3 Lindemann, “Counter the Counterstory," 286. 
None of this tells us specifically what he will say, or do, in a particular situation, but it gives us a general orientation toward him as a character, guides what surprises us and what does not.

Second, giving uptake to a character as a particular stock character does not mean that they cannot ever act out of character. One of the many reasons Casablanca is a great work is precisely the way that Rick breaks out of his mold as the familiar world-weary cynic, first in rejecting the great romantic love of his life, and second in embracing his beautiful friendship and returning to the cause. But he does these things as a world-weary cynic would. To be of a type does not mean one cannot break that type in particular actions, even actions that appear, as these do, destined to move one out of type. But first, these actions are unexpected. We are startled that Rick gives up the girl to his romantic rival. We are inspired and thrilled that he walks into the sunset with Louis. And second, unlike actions in type, they call for explanation. We need to understand that it is because the problems of three little people do not amount to a hill of beans in this crazy world that he is rejoining the fight. These things play their narrative role precisely as acts of originality, of defiance of who he is, in exactly the way that his drinking away his sorrows with Sam or cynically bantering do not.

Finally, none of this is explicit. To understand someone as of a certain type is not to consult a theory, or even to be consciously aware of what aspects are typical and which atypical. It is, rather, what Heidegger calls an engaged mode of "Being-with," a smooth skillful habit of engagement with someone.

And what holds for fictional characters holds as well for real ones. We understand people as instances of various stock characters and that understanding guides our interactions with them in the same way that our understanding of fictional characters guides our interpretations. That, at least, is my suggestion for fleshing out the relation between widely available social narratives and our interpretations of one another: these narratives construct for us a wide range of stock characters, and we then read one another as instances. ${ }^{4} \mathrm{I}$ am an academic, a radical activist, a nerd, a father, and a musician — each with its own small range of stock characters that give me a sense of what that means. I perform daily actions that are in role, and when I run into conflicts or novel situations, my understanding of these characters provides a framework within which to think things through. Just as important, and crucial to Lindemann's account of holding us in personhood, others understand what I am doing in these terms as well: Lance

4 Of course it is not only narratives that do this. The actual lives of people we grow up witheither family and friends or those regularly in the news - can play the same role in constructing an understanding of a type. 
is off at a protest again; sure, that is what activists do. He missed the organizing meeting; yes, because he is a father and his daughter is sick.

\section{CONSTRAINING CHARACTERS}

There are a number of distinctions worth noting in the way we inhabit stock roles and the ways that they can harm us. Some of our roles we choose-philosopher, chess player-while others are largely outside our control, socially assigned on the basis of various observable features, with no input from the person assigned to that role-man, member of family $x$, perhaps in some cases religious affiliation. $^{5}$

Socially imposed roles are particularly problematic. Even if not inherently oppressive, a role that one has no hand in authoring might simply not fit one's skills, self-understanding, or goals and even if it does, the idea that there is a dimension of identity that is outside one's autonomy might itself be problematic. Thus, even in masculinist societies, the imposition of the category man, and the associated stock character, could oppress someone who cannot live a flourishing life under that designation, for whatever reason. But having a role in the choice hardly guarantees that roles are unproblematic. Most obviously, one might have a forced choice between equally unpleasant alternatives. One might argue that being an employee in a capitalist system is inherently alienating. If so, then the fact that one can choose which capitalist to sell one's labor to does not remove the worry.

Some characters are subject to specific rules as a result of the stories that constitute them. Perhaps the Hippocratic oath is an essential element of our social stories of doctors, or a rule of fidelity of our stories of spouses. ${ }^{6}$ Other times, there may be no explicit statement of the rule, but a norm emerges as a consistent aspect of a whole range of stories: "students should sit in their desks and raise their hand for permission to speak" (Lindemann's example), "women should be submissive," "fighters should be brave and protect the innocent."

5 There are also intermediate cases in which input into the social kind is neither purely voluntary nor socially given. Friendships, musical genres, and statuses like geek or hip, etc., have complicated entrance (and exit) conditions that involve a dialectical interaction between individual and social group. Cf. Lance and Kukla, "Intersubjectivity and Receptive Experience."

6 The idea is not that one must follow these rules to be an instance of the character. Any rule can be violated. The point is that to be of type $t$ is to be subject to rule $\mathrm{r}$. If one is not a doctor, there is no Hippocratic oath to violate, and if one is a doctor, then not following it is a violation. 
Whether explicit or implicit in stories, these rules sometimes emerge as implications of seeing someone as a student/woman/doctor/fighter because they are central to all the relevant narratives.

Sometimes stories do not structure their characters as explicitly around rules as they do around characteristics: female lovers are blond and thin, male lovers are muscular and thin. Not that any social story is likely to suggest that such a character is always this way-if so, then we might as well treat that as a rule-but they can define a sort of paradigm or default. An instantiation of the character with the paradigmatic quality is "normal," unexceptional, not needing comment. Again, those who differ from the paradigm call for special explanation. This aspect is often remarked on in the context of race-the default framing of many characters is that they are white.

Such default assumptions can be their own sort of societal burden, even when it is possible to go against the default assumption. To always have to explain oneself, to be constantly subject to interrogation or even curiosity, to always be the atypical example of the type-all of these can be a form of social exclusion in the right context.

Similar default assumptions about characters apply to paradigmatic courses of action. Perhaps the standard story of the son is that he follows in his father's career footsteps, of the young woman that she will welcome flirtation and be on the lookout for a husband. Again, the imposition of such an assumption implies that anyone violating it becomes something of a rebel, or at least socially defiant. To occupy the social position without that course of action is to challenge existing normative assumptions. On top of that, deviant versions of a character may themselves become stock characters - the model minority, the perfect protestor, etc.-which can bring their own oppressive possibilities. By giving us standing default assumptions about the behavior of those defying a given role, they create a new role, often with a burden of double-defiance.

It is also possible to be harmed by the impossibility of inhabiting a particular character. This is most obviously the case when a role did exist and centrally structured the lives of real people only to have the material or social conditions necessary for its continuation forcibly removed. Jonathan Lear describes a particularly poignant and systematic removal of narrative possibility in Radical Hope, where he explains the utter destruction of the way of life-and possibilities for narrative understanding - of the Crow after the massacre of the buffalo and the people's imprisonment on reservations. ${ }^{7}$ But even if what is at issue is not the destruction of existing narratives, I think we can call it a form of harm when a society simply does not allow certain stock characters to exist, if those 
characters would facilitate the flourishing of people in the society. The emergence of various queer/genderqueer identities has been liberatory for people not comfortable identifying with the categories previously in existence in society, and arguably social resistance to the emergence of these stock identities was a harm. It seems to me that there is a positive social duty-defeasible of course and subject to all manner of trade-offs and resource issues - to promote the development of the practices inherent in potentially flourishing new identities.

Narratives can also frame stock characters within certain contexts or in conceptual terms that are harmful, even if the character itself is not, and sometimes that harm affects more than just the person who might inhabit the character. Think of the way that contemporary accounts of work/labor frame it as essentially commodified, thereby obscuring the very possibility of free productive labor. Or think of the many stories of "the racist." Repeated characterization of racists as explicitly vicious Klan members, even if they are presented as villains, reinforces the assumption that this is the only way to be racist. Thus, the more commonplace ways that we are complicit in, facilitate, or simply fail to challenge white supremacy become invisible through the very stories that institute the stock character of the racist. Or again, consider the very grammatical framing of a character such as "disabled person." We introduce the character via a oneplace operator on persons. That is, "disabled" appears in typical narratives as a property of an individual, rather than, say, as a relation between an individual and an environment.

There is certainly much more to say in this regard. The forms and textures of oppressive social narrative are many, and underexplored. But I will leave it at that for now, and turn to an even more brief survey of varieties of resistance.

\section{RESISTING, REFORMING, AND DESTROYING CHARACTERS}

Lindemann focuses primarily on the process of creating counterstories and the ways that dominant narratives can resist that process. In this final section, I want to begin addressing the rich variety of ways that people go about countering oppressive or harmful stock characters.

Sometimes we try to reform the nature of a given stock character. Lindemann considers the \#MeToo movement, which fits this category. The idea is to counter aspects of the stock character "woman," in particular the way such a character is expected to respond to unwanted sexual aggression. A number of aspects and behaviors come to be expected or interpretively privileged in our understanding of male-female sexual aggression: the well-meaning but awkward guy who goes a bit too far, or the vindictive woman who regrets sex, is out to get men, etc. As 
Lindemann emphasizes, the movement functions as much to challenge these narrative conventions as it does to remedy particular wrongs by particular people. And in the fabric of stories that become public in this explicitly storytelling movement there emerge other versions of these characters-women asserting autonomy, men succeeding (or failing) in making a proper apology or appropriate restitution, new restorative and, indeed, punitive potentials, etc.

Related to this example, consider the early marches of ACT UP-thousands of angry, powerful gay men chanting "We're here; we're queer; get used to it!" This sort of public performance-and as public performative protest, I think it counts as a sort of narrative-took place in a context in which most Americans gave uptake to gay men as a stock character that is effeminate, passive, and closeted. This massive and directly challenging confrontation with that characterrepeated dozens of times in dozens of cities, together with the thousandfold repetition of the process of coming out-was an attempt to destroy our ability to habitually render people according to the oppressive narrative.

Sticking with the same movement, we saw two powerful responses to Lindemann's counter-counterstory strategy of "making the language pretty." Early on in the AIDS epidemic, mainstream society took up one of two stances: the outright hostility of many religious and conservative political leaders who claimed that the disease was God's punishment or a predictable result of moral weakness; or on the other end of respectable opinion, those who counseled care and compassion for the dying, the victims of a "terrible tragedy." This latter response, emotive compassion, arguably made the response to systemic heterosexism pretty and acceptable in a way that diverted the radical potential of the movement. But ACT UP was having none of this, understanding that the death toll was as much a function of institutional decision as it was of natural process, and calling out the hypocrisy of caring for the dying, while encouraging the closet and systemic discrimination for the healthy. One concrete performative manifestation of this response to prettying the language was the much-used slogan of the movement: "Everyone loves a dying fag!"

Even more directly rejecting of liberal attempts to pacify and tame the movement: ACT UP members who had lost loved ones took to hurling their ashes into the faces of hostile politicians and religious leaders. It is very hard to continue conceptualizing someone as an instance of the passive, effeminate stock character after such an action.

Of course there are dangers to such tactics, and ways that the dominant narrative can react- the creation of new altered stock caricatures of the angry, intolerant gay man-but such is the dialectical nature of social change. ${ }^{8}$

8 The social enforcement of even the most absurd myths about marginalized groups is often 
A stock characterization of pacifists—-going back to the introduction of the word "Quaker" as a slur for the Society of Friends, indicating that they quaked in fear-has it that they are motivated by cowardice or lack of discipline. The civil rights movement worked hard to undercut this story of nonviolence, both in the writings of Dr. Martin Luther King Jr. and others that emphasized the courage necessary to confront violence, oppression, and racism without fighting, and in the practice of trained cadres that endured torture, imprisonment, and murder without breaking movement discipline. The portrayals of these brave men and women in the press constituted a counter-narrative that unsettled the dominant conception.

Evocative literature, then, often produces a different account of a negatively portrayed character. But it can also undercut the association of a negative trait with a particular character by associating it instead with a narrative opposite. Tim O'Brien's brilliant essay, "On the Rainy River," is a sustained reflection on his decision to go to Vietnam, rather than to resist the war by going to Canada. O'Brien recounts how he was afraid for his life and also morally opposed to the war-this was no opposition of principle and self-interest, for both pushed him toward Canada - but ultimately more driven by a fear of social disapproval, the mocking of friends and family. Embarrassment, he says, overcame the combined impetus of self-interest and morality. His essay ends with these words: "I passed through towns with familiar names, through pine forests, and down to the prairie, and then to Vietnam, where I was a soldier, and then home again. I survived, but it is not a happy ending. I was a coward. I went to the war." ${ }^{\prime 9}$ By associatingand evocatively rendering in rich detail - the way that participation in warfare could be cowardly, O'Brien undercuts the association of that trait with the stock character of the war resister.

Humor and absurdity can also destabilize our understanding of stock characters. Think here of the actions of Yippies, performative, queer, street-theater groups like the Lesbian Avengers, who performed in what became known in the 1970 and '8os as "Temporary Autonomous Zones." In each case, the goal is not

not subtle. I came to Georgetown University in 1991. A professor in the philosophy department at the time wrote an article in the campus newspaper that year claiming that ACT UP was the moral equivalent of the Nazis, on account of its confrontational actions directed toward the New York Catholic Diocese, which had been a leader in promulgating antigay sentiments. I wrote a response piece that pointed out a few salient differences, such as that the Nazis launched the Holocaust and a world war, whereas ACT UP had not physically harmed anyone. His response to this was to refuse to speak to me for the remainder of his tenure at Georgetown and to tell students that I endorsed killing Catholics. Sadly, such hysterical reactions to the counternarrative actions of ACT UP were not unusual. 
so much the creation of a concrete alternative to existing stock characters, but the unsettling of their place in the social psyche. When Yippies tossed dollar bills onto the trading floor of the New York Stock Exchange, the idea was less to construct a new image of capitalism and its various characters and more to simply break the spell of a particular narrative - to make traders look absurd.

Sometimes the creation of counter-narratives involves the creation of quasi-separatist communities. Such communities might produce novel understandings of a given character, or new characters entirely. In some cases, there is little effort to then integrate the new characters into the broader social understanding-e.g., Amish and other religious communities that seek only marginal integration - and other times local experiments burst out and demand broader recognition-for example the Stonewall riots, or various communes, anarchist communities, and collectivist squats that see themselves as prefiguring an anticapitalist way of life. ${ }^{10}$

As Lindemann says, there are no recipes here. For every counterstory tactic, there is a counter-counterstory retrenchment, dismissal, mischaracterization, etc. For every list of tactics on either side, it is possible to generate new ones. But the creative possibilities for dismantling oppressive narratives and the construction of new possible identities is enormously rich and an ongoing field of social contestation. To resist, reform, destabilize, and reconstruct the stock characters that provide the narrative grounding of our holdings of one another is part of what it is to be human. As such, it is a welcome subject for philosophical reflection.

Georgetown University lancem@georgetown.edu

\section{REFERENCES}

Lance, Mark, and Rebecca Kukla. "Intersubjectivity and Receptive Experience." Southern Journal of Philosophy 52, no. 1 (March 2014): 22-42.

Lear, Jonathan. Radical Hope: Ethics in the Face of Cultural Devastation. Cambridge, MA: Harvard University Press, 2006.

Lindemann, Hilde. "Counter the Counterstory: Narrative Approaches to Narratives." Journal of Ethics and Social Philosophy 17, no. 3 (June 2020): 286-98.

10 For a theory and detailed case study of such processes of identity construction, see Shotwell, Knowing Otherwise, esp. ch. 5. 
. Holding and Letting Go: The Social Practice of Personal Identities. Oxford: Oxford University Press, 2014.

O’Brien, Tim. “On the Rainy River." In The Things They Carried, 37-58. Boston: Houghton Mifflin Harcourt, 2010.

Shotwell, Alexis, Knowing Otherwise, University Park, PA: Penn State University Press, 2011. 